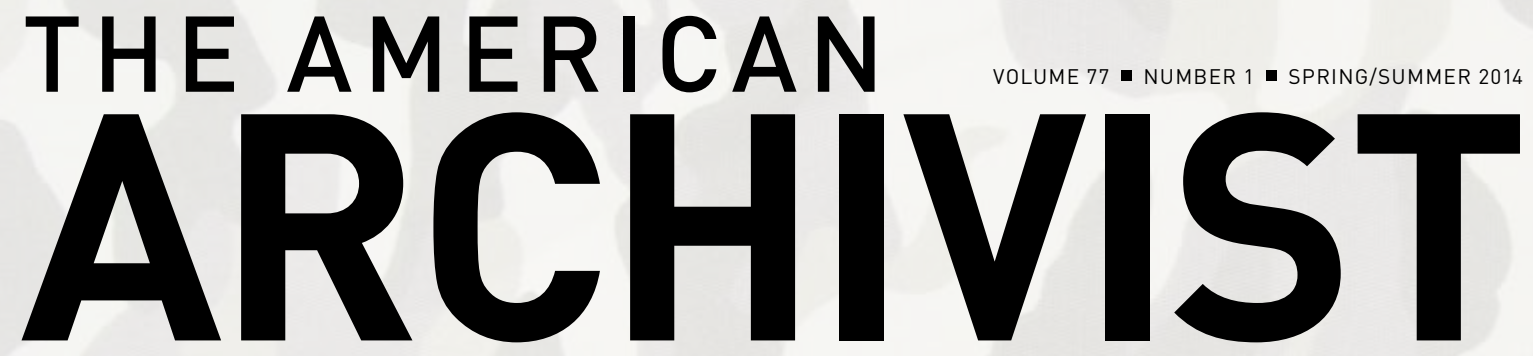

PUBLISHED BY THE SOCIETY OF AMERICAN ARCHIVISTS - WWW.ARCHIVISTS.ORG

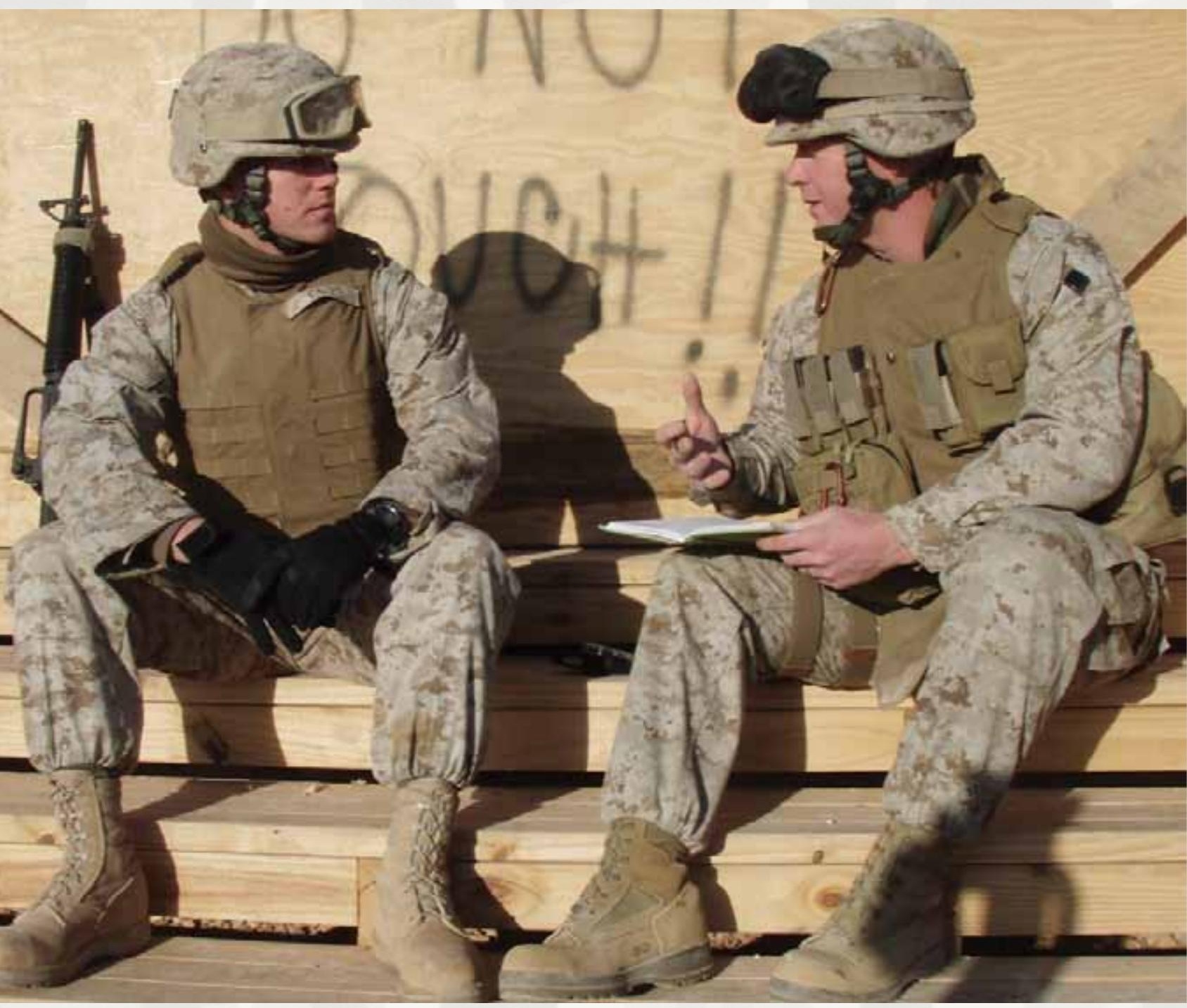


THE AMERICAN ARCHIVIST EDITORIAL BOARD

EDITOR

Gregory S. Hunter (2012-2014)

Long Island University

Brien Brothman (2008-2015)

Rhode Island State Archives

Todd Daniels-Howell (2012-2016)

Indiana University-Purdue University Indianapolis

Karen F. Gracy (2013-2017)

Kent State University

Thomas Hyry (2012-2016)

University of California, Los Angeles

\author{
Reviews Editor \\ Amy Cooper Cary (2011-2014) \\ Marquette University
}

Christopher (Cal) Lee (2008-2016)

University of North Carolina at Chapel Hill

Katie McCormick (2012-2016)

Florida State University

Jennifer McDaid (2013-2017)

Norfolk Southern Corporation

Jennifer Meehan (2011-2015)

Emory University

\section{GENERAL INFORMATION}

The American Archivist (ISSN 0360-9081) is published semiannually (Spring/Summer and Fall/Winter) by:

The Society of American Archivists

17 North State Street, Suite 1425, Chicago, IL 60602-3315 USA

Tel 866-722-7858 or 312-606-0722 Fax 312-606-0728 www.archivists.org

(1) () by the Society of American Archivists, 2014.

Except where otherwise noted, content in this issue is licensed under a Creative Commons Attribution Non-Commercial 3.0 United States License. Some rights reserved.

Institutional subscription rate

- \$209 print

- \$209 online

. \$259 for both print and online
Individual subscription rate

$\cdot \$ 169$ print

- \$169 online

- \$199 for both print and online

Online editions of The American Archivist, including the entire back run from 1938 to date, are hosted by MetaPress and may be accessed at http://archivists.metapress.com/.

\section{CONTACT US}

Articles and Ideas:

Gregory S. Hunter, Editor

AmericanArchivist@archivists.org

Reviews (books, exhibits, tools, resources): Amy Cooper Cary, Reviews Editor reviewseditor@archivists.org

Alexandra Orchard, Reviews Portal Coordinator af3973@wayne.edu

\author{
Production and Advertising: \\ Teresa M. Brinati, Director of Publishing \\ tbrinati@archivists.org
}

Anne Hartman, Editorial and Production Coordinator ahartman@archivists.org

Subscription and Claims (must be received within four months of issue publication date): servicecenter@archivists.org

\section{ABOUT THE COVER}

Documenting the American military experience in Iraq and Afghanistan presents new challenges for archivists. In this issue, Heather Soyka and Eliot Wilczek discuss the nature of counterinsurgency warfare and its implications for recordkeeping and documentation. One aspect they explore is the role of oral history in the twenty-firstcentury warfare environment. This photograph shows an oral history interview taking place on January 14, 2007, in Iraq. On the left being interviewed is L. Cpl. Travis J. Eno, United States Marine Corps (later promoted to corporal), then serving with Marine Wing Service Support Squadron 374 as a heavy equipment operator working the flight line at Camp Korean Village, Anbar Province, Iraq. He is being interviewed by Lt. Col. Kurtis P. Wheeler (since promoted to colonel), a Marine Corps reservist whom the Marine Corps History Division activated as a field historian to collect historical materials and oral history interviews related to Marine Corps operations in Iraq. In an interesting twist, when not serving with the Marine Corps Reserve, Lieutenant Colonel Wheeler is a high school history teacher, and Lance Corporal Eno had been one of his students before Eno enlisted in the Marine Corps. Photo courtesy of the Library of the Marine Corps, Archives and Special Collections Branch, Quantico, Virginia. 


\title{
Documenting the American Military Experience in the Iraq and Afghanistan Wars
}

\author{
Heather Soyka and Eliot Wilczek
}

\begin{abstract}
This essay reviews the challenges of documenting the American military experience in the Iraq and Afghanistan wars. It looks at the appraisal challenges presented by the complexities of counterinsurgency warfare. It then examines the nature of current military records with a focus on their volume and mix of structured and informal documents and data. Finally, it reviews the recordkeeping challenges faced by the military during these two wars. This essay addresses issues of broad archival concern beyond just military records: documenting complex activities and events, appraising big data and informal data, and effectively managing active records. ${ }^{1}$
\end{abstract}

(c) Heather Soyka and Eliot Wilczek. (cc) BY-NC

\section{KEY WORDS}

Electronic Records, Records Management, Archival Records, Appraisal 


\begin{abstract}
A merica's engagements in the wars in Iraq and Afghanistan have come at a significant cost to the United States. As of January 15, 2014, a total of 2,304 American service members and Defense Department civilians have been killed supporting Operation Enduring Freedom (Afghanistan), and 4,489 have been killed supporting Operation Iraqi Freedom and Operation New Dawn (Iraq). In the two conflicts, 51,810 U.S. personnel have been wounded in action. ${ }^{2}$ Both wars come at a combined estimated monetary cost of \$3.1 trillion to the United States. ${ }^{3}$ These two engagements have presented this nation with the ongoing challenge of providing health care for veterans that will last at least fifty years. The two wars were a focal point, if not the focal point, of American foreign policy during the first decade of the twenty-first century. The experiences of Iraq and Afghanistan have dramatically changed the military. ${ }^{4}$ These two wars clearly merit careful documentation as part of our political, military, cultural, and community heritage.
\end{abstract}

The wars in Iraq and Afghanistan present several documentary challenges to the archival community and to our society as a whole. In this essay, we focus on three of these challenges. First, we explore the difficulties in documenting counterinsurgencies and the challenges of documenting a military that is undertaking a growing set of diverse tasks on behalf of American society. Second, we examine the U.S. military's challenges with creating and keeping the records that document operations in Iraq and Afghanistan. Third, we look at the nature of U.S. military records from the two wars with a particular focus on their size and complexity. The archival literature on accountability and public trust in government recordkeeping guides this essay. ${ }^{5}$ We make an underlying assumption that good recordkeeping fosters transparency and accountability in government actions and supports the relationship between government and the people. ${ }^{6}$

This essay is limited to a discussion about documenting the American experience of these two wars. More specifically, it focuses on challenges related to documenting the experience of the American military. While the military community encompasses military and Department of Defense institutions; individual service members and their families; and civilian communities that tightly revolve around the military, this paper primarily focuses on the documentation of the Iraq and Afghanistan wars through the operational records of the military branch services. Most of this discussion draws on the U.S. Army's experience with documenting its operations in Iraq. We do not fully address other issues that also have significant implications for the documentation of these two wars and future conflicts. These include transparency, openness, and operational security issues raised by WikiLeaks making close to 500,000 leaked U.S. military operational records from the Afghanistan and Iraq wars publicly available on the Internet. Other issues not addressed include the role of personal and 
unofficial documents in war, the military's extensive use of private contractors in the Iraq and Afghanistan conflicts, the government's increased dependence on clandestine operations, an emerging American foreign policy strategy that features a more light-footed approach to conflicts abroad, and the issue of government secrecy. This essay does not address the documentation of the broader American political discourse about the wars or responses to the conduct of both wars, such as antiwar protests. This essay also does not address the fight over Iraqi government records ${ }^{7}$ or the broader issue of archives and cultural artifacts being targets of destruction and theft during armed conflicts. ${ }^{8}$ Finally, documenting the American military experience in the Iraq and Afghanistan wars tells only one perspective of these conflicts and obviously is not synonymous with documenting both wars in their totality.

Despite focusing on the American military experience, this documentary challenge should engage not just those working in military archives and records programs but also a broad range of archivists, records managers, and digital curators. Addressing the concerns identified in this essay has wide applicability to the archives, records management, and digital curation fields. Documenting military engagement in extremely complex conflicts while the armed services are also charged with a range of tasks from fighting wars to rebuilding nations challenges archivists to think deeply about what they are trying to document and what they are trying to achieve when making appraisal decisions. Managing and preserving the sea of U.S. military data clearly intersects with other efforts to manage and preserve research and government datasets and generally fits within the rubric of big data. Finally, the military's recordkeeping struggles demonstrate the critical importance of developing and implementing plans to protect and carefully manage records throughout their life cycle, not just when and if they reach the archives.

\section{The Nature of Counterinsurgencies}

Documenting the Iraq and Afghanistan wars requires an understanding of the nature of these conflicts. Archivists have historically engaged with questions related to selection and the growing volume of official war records. ${ }^{9}$ The distinct characteristics of counterinsurgency (COIN) warfare, however, suggest the need to consider different appraisal approaches for documenting counterinsurgencies than for documenting conventional wars. Appraisal of these military records also requires an understanding of the role that the military-which engages in these conflicts on this country's behalf-plays in our society. ${ }^{10}$

The Department of Defense currently defines counterinsurgency as "comprehensive civilian and military efforts taken to defeat an insurgency and to address any core grievances." 11 Counterinsurgencies are inherently complex 
undertakings that emphasize coordinated civil-military efforts, with political actions often having more strategic importance than combat operations. Documenting COIN is not just about documenting battles and combat. The prominent roles of small military units and nonkinetic activities ${ }^{12}$ in COIN campaigns present particular challenges to archivists attempting to document counterinsurgency operations.

In both the Iraq and Afghanistan wars, insurgencies emerged to challenge the Iraqi and Afghan governments, both put in place by the United States after its initial invasion and overthrow of the Saddam Hussein and Taliban regimes. In Iraq, the United States was slow to respond effectively to the growing insurgency and emerging civil war. From 2003 through 2006, American forces tended to focus on killing the enemy, transitioning security operations to Iraqi police and armed forces, and withdrawing U.S. troops to large bases in Iraq on the theory that the American presence was a cause of instability. It essentially took the military more than three years to reorient itself to formulate and carry out an effective COIN strategy in Iraq. ${ }^{13}$

During that time, a cadre of military officers, academics, and analysts contended that the American approach to the Iraqi insurgency and burgeoning civil war was poorly executed and fundamentally misconceived. Building on classic twentieth-century COIN literature and pointing to early isolated successes that some American units had in Iraq, COIN advocates urged U.S. civilian and military leaders to fundamentally change course and undertake a robust counterinsurgency campaign. These COIN advocates contended that U.S. troops should be an active presence in Iraqi communities and that the United States should focus on protecting the civilian population and politically isolating, rather than killing, the insurgents. The role of the U.S. military, they claimed, was to make it in the self-interest of the population to support the host government rather than the insurgents. ${ }^{14}$ The renewed counterinsurgency campaign undertaken by the United States in Iraq starting in 2007 differed significantly from conventional military operations.

Over the course of 2005 and 2006, the call for embracing counterinsurgency approaches and principles gained broader and higher-ranking support, culminating in the updated and fully revised publication of the U.S. Army and Marine Corps Counterinsurgency Field Manual in December 2006. Army general David Petraeus, who played a key role in overseeing the publication of the field manual, led a renewed effort and new approach to the war that embraced these COIN principles as he took command of all U.S. and coalition troops deployed in Iraq, officially known as Multi-National Force-Iraq, in January 2007. As part of this new approach, the Bush administration sent nearly thirty thousand additional troops to Iraq, in a strategy commonly referred to as "the surge." 
Small units-special forces teams, companies, platoons, and even squadsplayed a central role in this new strategy for the Iraq War. The key feature of the 2007 troop surge was not the additional numbers of American troops, but how the military deployed these forces. Instead of continuing to cluster troops on large, fortified bases that isolated American forces from Iraqis, the military embedded small teams of Marines and soldiers in urban areas, often in abandoned houses and other buildings. ${ }^{15}$ Rather than driving through a neighborhood "in an armored convoy, day-tripping like a tourist in hell," before returning back to base, ${ }^{16}$ the military aimed to make small units constant, trusted presences within Iraqi communities. This strategic plan placed a premium on activities like frequent foot patrols and regular meetings with local leaders. The goal of embedding U.S. troops within Iraqi communities was to provide a secure space to support political reconciliation and to convince Iraqis that it was in their best interest to give the Americans information about insurgents and, more generally, to support the Iraqi government and coalition forces. ${ }^{17}$

David Kilcullen suggested that establishing a constant presence among the population-just being there-is an essential component of any successful COIN operation. ${ }^{18}$ Routine activities, particularly nontransactional activities, can be surprisingly difficult to document as participants often do not consider those activities to merit recording because of their routine nature. For example, the daily staff journal, a critical document for capturing the activities of units down to the company level in combat zones, is designed primarily to capture events and is not meant for staff to "normally enter routine matters." 19 However, routine, nontransactional, "being there" activities may be among the most important of the Iraq and Afghanistan wars. The complex nature of counterinsurgency warfare, where critical actions are just as likely to take place in a brief, impromptu conversation between a civilian and a solider as to occur in a firefight, poses many challenging questions. What should we be trying to document when preserving the records of a counterinsurgency campaign? Do COIN campaigns and traditional warfare require substantially different documentation strategies? How do we document the routine?

Army history regulations, including those specifically addressing deployed units, identify document types that commanders must preserve. These instructions, usually presented as a table of document types, are easy to understand and are similar to records schedules in many industries. Army history doctrine and instructions generally describe appraising records and documenting activities as "collecting" documents. These document-centric instructions do not discuss appraisal and documentation or approaches like functional analysis at a strategic level. Even Field Manual 1-20, Military History Operations, which is written primarily for army historians, focuses on gathering document types. This and other policies thoroughly describe the types of documents to capture 
and how to capture them. ${ }^{20}$ However, no significant attention is paid to how documenting counterinsurgency operations may pose challenges that differ from documenting traditional warfare. For example, army history doctrine and policies do not indicate any difference between documenting the 2004 battles of Fallujah, which featured large assaults and intense, sustained combat, and the 2005 to 2006 counterinsurgency efforts in Tal Afar which, after an initial assault, consisted largely of patrolling, meetings and negotiations, improving infrastructure and government services, training police forces, and conducting targeted raids.

Successful counterinsurgency operations also depend on the effectiveness of small military units. The COIN-centric tactics used during the surge in Iraq and the mosaic nature of the war-with the state of the insurgency sometimes varying from block to block-pushed significant responsibilities down the chain of command to captains, lieutenants, noncommissioned officers, and even enlisted personnel. ${ }^{21}$ COIN theorists pressed military leadership to give small units like platoons and companies autonomy and the resources necessary to respond effectively and quickly to opportunities and threats based on their local knowledge of a small, specific area of operation. ${ }^{22}$

As small units in COIN operations often have strategic significance beyond what their size may suggest, the documentation of counterinsurgencies cannot rely solely on records from division or higher headquarters. If "rank is nothing ... [and] talent is everything" in COIN, ${ }^{23}$ the appraisal of military records needs to consider that the records of a smaller unit, such as a company headquarters, may, in some circumstances, contain more documentary significance than the records of the larger division headquarters. This, of course, is an appraisal challenge found with the records of any hierarchical organization, not just the military. Speaking about government records, Hans Booms noted that one cannot "make the a priori assumption that records from a president's office . . . are necessarily more significant than those from the office concerned with social security, even though the latter is on a much lower administrative level." ${ }^{24}$

The strategic significance of small actions by small units is also framed by the concept of the strategic corporal, a term coined by the commandant of the U.S. Marine Corps in 1999 to note the strategic significance of noncommissioned and junior officers in asymmetric warfare. ${ }^{25}$ Documenting the wars in Iraq and Afghanistan requires an understanding of the strategic importance of the actions of junior officers, noncommissioned officers, and enlisted personnel. ${ }^{26}$ Archivists can pair the strategic corporal and COIN principles with the records continuum to guide their appraisal decisions on the documentation of COIN operations. The records continuum demonstrates how records can be seen as not just narrowly documenting particular acts by individuals but also as having broad societal implications at the macro level. ${ }^{27}$ Within the records continuum, 
archivists are urged to appraise records not only in terms of the records creator, but also in terms of the subjects of the records, considering and accounting for the plural rights of multiple constituencies. ${ }^{28}$ This theory highlights the importance of having a broader understanding of the continuum of relationships from record, to act, to activity, to function, to institution, to society. The continuum and the strategic corporal concepts provide a framework for seeing the tactical, strategic, and geopolitical significance of operational military records.

While the wars in Iraq and Afghanistan have tended to push important tactical and strategic decisions down the chain of command, U.S. military history and archives resources are usually more robust toward the top echelons of leadership. Within the U.S. Army, for example, division and higher-level units are supposed to have dedicated historians, while units at the brigade and lower levels have earmarked historical and archival appraisal activities as an "additional duty as assigned." ${ }^{29}$ Broadly speaking, the U.S. government has scheduled a wide range of records from all units involved in the Iraq and Afghanistan wars as having enduring archival value. ${ }^{30}$ However, as discussed in further detail later in this article, the military has encountered significant challenges in attempting to preserve the records of units deployed in Afghanistan and Iraq.

Understanding the nature of counterinsurgency warfare is just one part of developing an appraisal strategy for the wars in Iraq and Afghanistan. Archivists also need to understand these wars within the context of how the U.S. military serves American society. What functions and activities does the military perform on our behalf? This is a deceptively complex question because American society expects the military to undertake a wide range of civil affairs activities overseas, deliver humanitarian aid around the globe, collect and analyze intelligence, play an active diplomatic role, patrol U.S. borders, support disaster response, and supplement the security of high-risk targets. ${ }^{31}$ The distinction between what the military does and what civilian government agencies do has blurred increasingly over the last decade. While the military has engaged in more tasks traditionally thought to be civilian activities, civilian agencies, especially the CIA, have engaged in what would generally be considered combat operations. ${ }^{32}$ In addition to challenging assumptions about what entities support which functions on behalf of the American people, this blurring of civil and military roles also calls into question what we consider to be military operations and warfare. ${ }^{33}$ The advent of cyber-warfare, for example, poses serious questions about defining the essential elements of state-sponsored warfare. ${ }^{34}$ Archivists need to be able to engage with the nature of contemporary war and the roles of the armed services to make informed documentation and appraisal decisions about the military and its records. 


\section{The Nature of Military Records}

To document the American experience of the wars in Iraq and Afghanistan, archivists also need to understand the nature of the records that the military creates. One of the most challenging characteristics of current military records is their volume. Appraisal, accessioning, arrangement, description, and preservation strategies for these records must be scalable if archives are going to successfully document American contemporary military operations. Because many military records have clearly defined record types with explicit rules for their creation and use, archivists may be able to leverage automated systems that can parse large volumes of records by their document types to help automate appraisal decisions. Any strategy to document the American military experience in Iraq and Afghanistan will also have to contend with records generated in informal settings, such as milblogs, ${ }^{35}$ online forums, and ad hoc workspaces, where the documentary form and warrants for creation are much less explicit. In addition, archivists and records managers also face significant appraisal and preservation challenges with still and moving image data produced by the military and intelligence agencies that lack transactional characteristics.

The United States military comprises a set of organizations that have always produced large volumes of records to support operations. Two long and large-scale wars along with advances in information technology have dramatically increased the scale at which the military and intelligence agencies generate records. For example, in March 2011, U.S. Central Command (CENTCOM) received forty-six terabytes of operations-level joint forces data from Operation Iraqi Freedom. ${ }^{36}$ The U.S. Army Center of Military History has collected ninetytwo terabytes of records from operations in Iraq and Afghanistan. ${ }^{37}$ In 2010, over eighty-five thousand paper-based detainee records from the Iraq War were shipped to the United States by the 777th Military Police Detachment of the Michigan National Guard to be digitized, cataloged, and processed for use by the Pentagon's National Detainee Reporting Center. ${ }^{38}$ These are only small slices of the U.S. military records documenting the Iraq and Afghanistan wars. One defense contractor noted in 2012 that the armed forces "currently have approximately 7 million computing devices-a number that is expected to double by 2020." 39 Each of those devices is capable of transmitting, storing, and creating records. Generating and collecting terabytes of records have become normal processes for the military and intelligence agencies.

Archivists must be able to manage records from the Iraq and Afghanistan wars on the terabyte scale. The successful management and preservation of these records will require a variety of approaches that combine archival practices with a range of tools that can scale this work. Ideally, institutions would manage records effectively in robust electronic recordkeeping systems, and archivists 
would use analytic tools to support scalable assessment, identification, classification, and other parsing and encoding work. ${ }^{40}$ William Underwood's work at the Georgia Tech Research Institute in partnership with the National Archives and Records Administration (NARA) provides an example of such an approach. Underwood and his colleagues built upon the diplomatics concept of documentary form to enable NARA archivists to rapidly appraise and describe hundreds of thousands of electronic presidential records in months rather than the years it would take to do this work manually. Underwood and his research partners developed XML encoded context-free grammars that define the documentary form of presidential memos. The grammars combine wordlists and semantic tagging of sample records to allow NARA to sort and classify presidential memos for their evidential value and security clearance concerns. ${ }^{41}$

Many military operational records are highly structured documents explicitly defined by rules. This suggests that they could be good candidates for approaches based on documentary form. Underwood's work suggests that an analysis of record types that examines their documentary form and function could be a promising strategy for appraising large volumes of military records. This approach is particularly important for operational records that may need to be appraised at the individual level for classification review or other reasons. Developing machine-readable definitions of document types should enable archivists to leverage digital tools to help them appraise records documenting operations in Iraq, Afghanistan, and future conflicts.

Any appraisal strategy for these records must also have the flexibility to recognize that many military records are now created in informal ad hoc environments that lack rules, structures, and warrants. During the wars in Iraq and Afghanistan, officers and troops frequently used informal spaces to conduct their work, even though those spaces often were not acknowledged or codified in formal recordkeeping rules and guidelines. Records related to the continued use of synchronous, text-based chat such as $\mathrm{mIRC}^{42}$ by military command-andcontrol centers during operations in Iraq and Afghanistan are significant to understanding how soldiers and commanders communicate on the battlefield. Lack of standardized tools, regulations, official support, and sponsorship for documenting these informal communications platforms means that critical information related to decisions made in-theater could be lost. In 2003, realtime chat became a core communications vehicle for command and control. During the first year of combat operations in Iraq, approximately twenty-five hundred chat users participated in over four hundred chat rooms to exchange tactical and situational information. ${ }^{43}$

Social media is another type of informal, lightweight, easy to implement recordkeeping environment that the military community uses extensively. The military's embrace of social media channels, however, has not always been 
easy. The development of personal military blogs (milblogs) exposed tensions between the military establishment and the individual. Written by active duty soldiers, the early scope of milblog activities provided an outlet for the personal experiences of war, in much the same way as diaries and letters functioned during previous conflicts. ${ }^{44}$ Gaining popularity as places to share and read an "unfiltered" account of activities in a combat zone, these information spaces eventually coalesced into a linked, broader milblog community that includes military spouses, recent veterans, security analysts, military historians, and other members of the broader military community. ${ }^{45}$ Because soldier-authored milblogs are, for the most part, scattered, unofficial creations of individuals, they are not captured as part of official documentation of the experiences of the wars in Iraq and Afghanistan. The varied form, structure, and presentation of these informal creations also blocks their potential capture, preservation, access, and use.

Several other informal environments have come to serve as digital "watering holes" for personal knowledge transfer between military leaders. Two examples are the websites CompanyCommand.com and PlatoonLeader.com. Established by officers seeking to share their command experiences and learn from others, these unofficial forums represent a recorded piece of the communication that occurs between officers about their professional lives, decisions, and leadership. ${ }^{46}$ The discussions mirror an older model of personal and professional knowledge transfer through interpersonal conversations and expand the usefulness of this information exchange about leadership, experiences, and training by enabling it to be shared with a broader network of people over time and space. Peer-to-peer conversations on websites such as Company Command and Platoon Leader form a bridge between leadership, unit, and officer knowledge, and they allow for the management and expansion of knowledge about particular situations and experiences. ${ }^{47}$

The widespread use of these forums and communications tools by officers reflects the reality that crucial information travels outside of traditional, hierarchical systems in the military. Officers and enlisted personnel use a mix of informal and formal environments to best support their work. Members of the military frequently find that informal spaces are more effective than formal systems for quickly creating and sharing information and supporting the work of ad hoc groups. This workplace reality is common to most industries. While the military is a hierarchical organization, it is also complex. Military records do not merely move up and down a simple chain of command, and many records that provide critical documentation of the wars in Iraq and Afghanistan are produced informally. For example, one of the most critical records documenting the development of the American COIN strategy in Iraq is a short PowerPoint presentation featuring stick figures that tells a story of defeating insurgents 
in $\mathrm{Al}$ Anbar province. ${ }^{48}$ In another example, David Kilcullen's “"Twenty-Eight Articles': Fundamentals of Company-level Counterinsurgency," a cornerstone in the current American COIN literature, started out as an email message before it became an article in Military Review. ${ }^{49}$ Archival appraisal strategies must account for this messy, dynamic mix of formal and informal recordkeeping environments, otherwise archives and records management programs will not have the flexibility to understand the significance of the full spectrum of records created during the Iraq and Afghanistan wars.

Another recordkeeping challenge emerging from these two wars is the management of observational data. The U.S. military and intelligence community must now manage vast quantities of moving and still image observational data recorded by unmanned aerial vehicles (UAVs) and other recording platforms such as unmanned undersea vehicles (UUVs), armored vehicles, and soldiers' helmets. For example, the number of the U.S. military's unmanned and remotely piloted aircraft-commonly called drones-has risen sharply over the past decade, from fifty-four operational U.S. Army unmanned aircraft in October 2001 (the start of operations in Afghanistan) to more than four thousand UAVs carrying out surveillance, reconnaissance, and intelligence missions in $2010 .^{50}$ Recently deployed by the U.S. Air Force in Afghanistan, a new wide-area surveillance sensor named "Gorgon Stare" is intended for the capture of "citywide" data. Able to transmit panoramic views to soldiers in real time, this remotely piloted aircraft is equipped with nine cameras that shoot two frames per second and generate mountains of data. ${ }^{51}$

Effectively analyzing these data troves for planning, lessons learned, and actionable intelligence has been a core challenge for the military and intelligence agencies. ${ }^{52}$ In April 2012, U.S. Air Force secretary Michael Donley noted that one reason for not immediately adding many more unmanned aerial vehicles to current operations was an attempt to catch up with the backlog of collected data. ${ }^{53}$ The core challenge related to these oceans of data is familiar to archivists and records managers: finding ways to sort, retrieve, and navigate information that could be relevant to current or future use. Existing visual intelligence algorithms can collate and process collected data, but still require human judgment to make decisions and draw conclusions.

Research is underway to develop methods to harness intelligence from this data. For example, the Defense Advanced Research Projects Agency (DARPA) has initiated a research program called "Mind's Eye" to develop smart cameras that will be capable of recognizing, describing, and predicting human activities using machine-based artificial intelligence. ${ }^{54}$ Early reports of this research at Carnegie Mellon University included the classification of human actions into verbs that can be applied within an ontological framework for identification. ${ }^{55}$ Like William Underwood's work at Georgia Tech, this research is developing 
machine-readable, scalable processes for making analytic decisions for classifying, characterizing, tagging, and applying rules and actions to data. These tools and processes must still be informed by policy decisions made by humans. However, while these and other tools are essential to applying appraisal policies to these data, they do not replace the human act of appraisal. Archivists will need to ask what these observational data troves are documenting. Does moving image data from a UAV attacking Taliban forces in Afghanistan merit enduring preservation? What about video of Taliban forces or American forces that are not engaged in a firefight? What about moving or still image data of terrain that does not contain any people, fortifications, or evidence of activity, such as vehicle tracks? Archivists and the military will have to consider if observational data has additional applications beyond supporting combat and intelligence operations. Does it support the development of doctrine and post-action lessons learned? Does it support historical analysis of the Iraq and Afghanistan conflicts? Does it support other research, such as environmental studies? Does the long-term evidentiary and research value of these data outweigh their enduring preservation and access costs?

\section{The Nature of Recordkeeping in Deployed Units}

Beyond the appraisal challenge of determining the nature and functional role of counterinsurgency operations and the archival management and preservation challenges that these war records present, this nation has faced the more fundamental challenge of enabling its military to consistently create and protect the records of its engagement in the Iraq and Afghanistan wars. In a series of 2012 ProPublica articles, Peter Sleeth described how the military has been unable to save significant portions of its operational records from the two wars, especially those created before $2009 .{ }^{56}$ The documentary record of many units deployed in Iraq and Afghanistan appears to be remarkably poor. The U.S. Army Center of Military History, for example, claimed that as of the end of 2008 it did not have sufficient records to write an "adequate . . history" for over ninety army units that had deployed in Iraq or Afghanistan. ${ }^{57}$ A NARA assessment in 2010 revealed that the military did not know the "volume, location, size and format" of records of Iraq-deployed units and that there were "large gaps in the records holding of CENTCOM and Service Components" in Iraq..$^{58}$

These documentation gaps present significant problems for the military, its service members and veterans, and our broader society. For the military, missing records hinder its development of lessons learned, training, and doctrine. Operational records provide the basis for unit histories, which are an important component of troop morale and establishing esprit de corps. For service members and veterans, operational records provide evidence for commendations and 
citations and are critical for protecting veterans' rights to heath care and other benefits. Veterans' advocacy groups have raised concerns about how missing records threaten these rights, and this issue has garnered congressional attention. ${ }^{59}$ More generally, these records play a critical role in the private memories of veterans and their families and the public memory of American societyto say nothing of the importance of these records for the people of Iraq and Afghanistan.

What caused these large gaps in the American record of these two wars? Confusion over recordkeeping authority, shortcomings in military records management capacity, concerns over operational security, and competing priorities all appear to have contributed to this problem. The 2010 NARA report indicated significant confusion and disagreement over recordkeeping responsibilities between CENTCOM and the branch services. This is caused, in part, by a lack of "clear guidelines regarding" records ownership. ${ }^{60}$ These disagreements have led to the poor management, and even loss, of records. ${ }^{61}$

The intense operational pace of the past decade also appears to have significantly challenged the military's-in particular the army's-capacity to manage its records effectively. In a 2009 report, Richard W. Stewart, chief historian of the U.S. Army Center of Military History, gave a brief historical overview of records management in the army and claimed that administrative changes and an increased focus on IT issues led to a "decline in Army record-keeping training and policy enforcement and a resulting decrease in the preservation of unit operational data." ${ }^{62}$ In Iraq and Afghanistan, evidence suggests that the military did not ramp up its records management capacity to meet the demands of two simultaneous wars. The 2010 NARA assessment of Iraq War records noted that CENTCOM did not have "a fully implemented records management program" or plans to retire records from the war. ${ }^{63}$ Guidance on capturing records had not been "fully implemented or disseminated" by $2010 .{ }^{64}$ While many high-level directives were issued about preserving records, Stewart claimed that these directives were not integrated with detailed procedures, training, and enforcement components as part of a "comprehensive, effective program." ${ }^{65}$ Indeed, despite general orders from the Pentagon and various military leaders to preserve operational records, many senior commanders in Iraq and Afghanistan have not made this a point of emphasis. ${ }^{66}$ In his 2009 report, Stewart also noted that "commanders of deployed units ... [claim that] they lack the expertise, time, and manpower to comply with what to them is an administrative burden." 67

The lack of focused time and personnel resources available for recordkeeping combined with myriad competing demands on deployed officers and noncommissioned officers have frequently made the retention and preservation of operational records a comparatively low priority. As the size of units gets smaller down the chain of command, it is not unusual for officers, NCOs, and enlisted 
personnel to take on multiple functions as needed. Preserving records, particularly at the lower levels of command, becomes-like many tasks-"another duty as assigned" 68 that competes with other priorities, such as combat engagements, force protection, logistics, intelligence operations, and civil affairs. While the army encourages commanders of units as small as companies to designate a commissioned or noncommissioned officer as their unit historians, this is still an additional duty ${ }^{69}$ Even when a unit has a designated historian, that officer or NCO will still have a multitude of tasks that are frequently more pressing and often perceived as more important than preserving documents. While the preservation of these records is critically important to the military and to protecting the rights and benefits of enlisted personnel and officers, these benefits can seem remote to troops engaged in complex, hectic, and dangerous combat and COIN operations. A RAND Corporation analyst noted, "in combat, battalion staffs tend to be shorthanded, overworked, and likely to focus only on those tasks that are going to prove useful to their primary mission." ${ }^{70}$ Many of the army's history manuals emphasize the importance of history, suggesting that many officers need to be convinced that recordkeeping and documentation are more than just bothersome administrative duties. ${ }^{71}$

In addition, officers have career incentives that discourage them from putting in the extra work to ensure the preservation of their unit's records. Usually officers advance their careers by accomplishing operational missions, not through exemplary recordkeeping. More specifically, concerns and confusion over operational security have encouraged units deployed in Iraq and Afghanistan to destroy rather than save records. It appears that confusion over whether units could transport classified records back to American bases or perhaps hypersensitivity to protecting classified records has led to the destruction of a notable volume of operational records. ${ }^{72}$ In addition, restrictions on the use of portable storage devices have brought some records collection efforts by history units to a halt. ${ }^{73}$ Because breaching operational security (OPSEC) can have a detrimental effect on an officer's career and potentially deadly consequences for troops on the ground, officers have every incentive to err on the side of OPSEC caution. These circumstances have led to the destruction of records that should have been preserved.

The military has not been without some preservation successes. In 2009, NARA formed the War Records Group, which has worked closely with CENTCOM to identify operational records for enduring retention. CENTCOM took extensive measures to secure approximately fifty terabytes of records and is preparing them for their future transfer to NARA. In addition, CENTCOM has been actively working on capturing and preserving records since $2006 .{ }^{74}$ In an effort to improve the recordkeeping culture of the Marine Corps, the Marine Corps Archives and Special Collections successfully included training 
for writing command chronologies into the curriculum of the Expeditionary Warfare School. ${ }^{75}$

Military History Detachments (MHDs) are another bright spot in the effort to preserve military records from the wars in Afghanistan and Iraq. MHDs have gone to extraordinary lengths to collect copies of records, take notes at meetings, conduct interviews of key personnel, and write short histories of operations. In some instances, it appears that these MHDs have collected the only extant copies of unit records. ${ }^{76}$ Much of the success of MHDs appears to hinge on the persuasiveness and perseverance of the individuals in these detachments. ${ }^{77}$ Such attributes are needed to overcome the reluctance of some commanding officers of deployed units to cooperate with MHDs or have historians attached to their units. The Military History Operations army field manual dryly notes, "operational commands do not always fully appreciate the benefits and value of taking historians with them during their operations."78

Despite these efforts, MHDs are not a scalable solution for systematically documenting the wars in Iraq and Afghanistan or other military operations. MHDs are typically three-person teams, and, as of 2009, twenty-four MHDs had deployed to Iraq or Afghanistan. ${ }^{79}$ In addition to MHDs, small teams from the Center for Army Lessons Learned and other military centers and contractors such as the RAND Corporation are also sent to the field to collect documents and interviews. ${ }^{80}$ This assortment of teams does not have the capacity to capture records systematically. For example, when the 305th MHD deployed to Afghanistan in 2007, it was the only MHD in the country and the first historical unit in Afghanistan in over three years. ${ }^{81}$ In addition, the core mission of the MHDs, along with unit historians at the division or higher levels, is to collect documents and interviews to support the creation of unit and operational histories. While they have captured critical documents, these efforts are not fully integrated with military records management efforts to manage all records appropriately and capture all records of enduring value systematically.

The military's documentation of its operations in Iraq and Afghanistan has gained broader attention since publication of the 2012 ProPublica series. ${ }^{82}$ In particular, Congress asked the Department of Defense to answer a series of questions about gaps in the records of deployed units. ${ }^{83}$ The U.S. Army acknowledged that gaps currently exist in its operational records from Iraq and Afghanistan. In a letter to two members of Congress, the secretary of the army conceded that "although numerous directives have been issued to emphasize the importance of the preservation of records, these directives unfortunately were often overcome by other operational priorities and not fully overseen by commanders." 84 The secretary pointed to "the austere, hostile environment and high operational tempo" of the wars as the primary causes of these recordkeeping shortcomings. ${ }^{85}$ In an effort to close those gaps, the secretary of the army and the army 
chief of staff issued a July 1, 2013, memorandum ordering all army elements that served in Iraq and Afghanistan to copy and transfer all of their operational records to the U.S. Army Center of Military History by December 31, 2013. ${ }^{86}$ The memo noted that the goal of this effort was to "establish a consolidated Armywide repository of war records.” The Center of Military History, in coordination with the U.S. Army Records Management and Declassification Agency, "will be responsible for structuring and organizing the records and determining the 'completeness' of Army operational records" from the two wars. ${ }^{87}$

The specter of the military's failure to document properly its operations in the 1990-1991 Gulf War hangs over the current effort to document the Afghanistan and Iraq wars. In its current history regulations and doctrine, the army uses the failure of the military to properly document activities in the Gulf War as a reminder to unit commanders of the importance of preserving records. One guide noted that poor recordkeeping during Operation Desert Storm forced the army to spend millions of dollars to reconstruct where and when units and individuals were located to investigate the causes and medical claims for Gulf War syndrome suffered by many deployed troops. ${ }^{88}$ Another army handbook on managing operational records for unit commanders begins with a page-long narrative about the problems caused by poor recordkeeping in the Gulf War. The handbook noted that troops suffering from Gulf War syndrome "faced an uphill struggle in proving they were anywhere near combat operations or even in the theater at all" because records were not properly kept. ${ }^{89}$ The U.S. military clearly has an institutional memory of its recordkeeping and preservation shortcomings in the Gulf War. In fact, just as the Iraq and Afghanistan wars have reinvigorated the memory and debate over the Vietnam War within the military and throughout our society, the military's current documentation and preservation challenges seem to have refreshed the memory of the military's Gulf War recordkeeping woes. This memory, however, does not appear to have been enough to prevent some of these failings from happening again.

\section{Conclusion}

This article looked at three core challenges of documenting the American military experience in Afghanistan and Iraq. Understanding the nature of these wars is critical to making informed appraisal decisions about the military records produced during these conflicts and for developing approaches that effectively address the myriad challenges related to these and future counterinsurgency and peacekeeping operations. Archivists and records managers must grapple with the immense volume and complexity of these records. Part of the challenge of documenting these conflicts also has been overcoming the difficulties in systematically creating, managing, and protecting operational records in-theater 
and safely transferring them to preservation environments. Any effort to document a conflict will take multiple archives to preserve the spectrum of personal and official war records. ${ }^{90}$ Archivists must also engage with records managers and records creators during armed conflicts to make arrangements for the comprehensive preservation of operational records. Effectively documenting conflicts also requires addressing systemic recordkeeping challenges within the U.S. military. Deployed officers do not have the incentives to ensure the careful management and preservation of their operational records. The military must change these incentive structures or implement technologies that make the easiest recordkeeping choice for officers the best recordkeeping choice for the records. The records community needs to partner with the military to develop processes that shorten the path from the battlefield to the archives.

Records declassification and government secrecy more broadly are beyond the scope of this article, but this issue clearly affects the documentation and collective memory of the Iraq and Afghanistan wars and other conflicts. Large military operations are relatively open and transparent activities compared to limited logistical and aerial support, small training and advisor efforts, clandestine operations, cyber-warfare, and the use of contractors and other thirdparty actors that the American government now seems to favor. Addressing the challenge of government secrecy is another important aspect of documenting American foreign policy and overseas operations. ${ }^{91}$ Although government leaks have existed throughout American history, WikiLeaks has pushed this issue to the fore and challenged archivists to think deeply about the role of records and secrecy in documenting government activities. ${ }^{92}$

Concern over veterans' rights may significantly improve the systematic documentation of military operations. As the U.S. military has disengaged from the conflicts in Iraq and Afghanistan, the concern over the preservation of operational records has become an important issue for veterans' rights. The absence of operational records presents significant obstacles to veterans trying to claim their medical benefits. Veterans' advocacy groups and congressional committees on veterans' affairs are driving current concerns in Washington over the military's recordkeeping shortcomings. ${ }^{93}$ Missing or incomplete military records are usually discussed in conjunction with the Veterans Administration's recordkeeping challenges and the delays that veterans face in receiving benefits. Framing the management and preservation of military records as a veterans' rights issue may be the most effective strategy for marshaling the necessary political will to improve military recordkeeping. ${ }^{94}$

The goal of this essay is not only to help foster and frame a discussion about effective strategies to document America's engagement in the Iraq and Afghanistan wars, but also to engage in an active conversation about documenting conflicts and other complex endeavors-such as addressing the challenges 
of protecting human rights, reducing crime, improving education, and alleviating poverty-undertaken by large, dynamic institutions in the twenty-first century. This work requires a full spectrum of skills and actions. Archivists need to understand the messy functions of large organizations and the nature of complex events. They need to partner with records creators to develop and implement recordkeeping systems that facilitate records preservation and be tools people want to use to support their daily work. Archivists need to use tools that can parse and process large volumes of records. Finally, archivists need to understand the role of these records in the development of a society's collective memory because "who gets remembered with monuments and who gets erased from history depends to some substantial degree on archivists and the records they preserve." ${ }^{95}$

\section{NOTES}

1 The authors would like to acknowledge the assistance of Paul Wester Jr., the support of the IMLSfunded Archival Education Research Institute (AERI), and the organizers of the SAA Research Forum. A fortuitous conversation with Mr. Wester after the 2012 SAA Research Forum in San Diego helped shape our thinking at a critical point in the writing process. The AERI conferences provided a focused space for us to discover overlapping research interests and to discuss and move forward on this article. We presented early versions of this paper at the 2011 and 2012 SAA Research Forums.

2 Department of Defense, U.S. Casualty Status (Washington, D.C.: Department of Defense, January 15, 2014), http://www.defense.gov/news/casualty.pdf.

3 Estimates vary on direct and indirect costs, depending on what is included. The \$3.1 trillion figure is from the "Costs of War" project, Eisenhower Study Group, Estimated Dollar Costs of Wars, in \$Billions (Providence: Brown University, 2013), http://costsofwar.org/article/economic-cost -summary. This study draws from publications by the Congressional Research Service, the Department of Defense, and the Congressional Budget Office, and includes budgetary costs, military salaries, homeland security, veterans' benefits, and interest already paid. The Eisenhower Study Group estimates that the cost of the wars including future spending and obligations will be over \$3.9 trillion. For additional details, see Amy Belasco, The Cost of Iraq, Afghanistan, and Other Global War on Terror Operations Since 9/11, CRS Report for Congress (Washington, D.C.: Congressional Research Service, March 29, 2011); K. Alan Kronstadt, Pakistan-U.S. Relations: A Summary, CRS Report for Congress (Washington, D.C.: Congressional Research Service, May 16, 2011).

4 Chad C. Serena, A Revolution in Military Adaptation: The U.S. Army in the Iraq War (Washington, D.C.: Georgetown University Press, 2011); Sarah Sewall, “A Radical Field Manual," in The U.S. Army / Marine Corps Counterinsurgency Field Manual (Chicago: University of Chicago Press, 2007); Fred M. Kaplan, The Insurgents: David Petraeus and the Plot to Change the American Way of War (New York: Simon and Schuster, 2013).

5 Discussion of the roles that records play in society and the intersections between recordkeeping, ethics, and government accountability in the archival literature includes the volume edited by Richard J. Cox and David A. Wallace, Archives and the Public Good: Accountability and Records in Modern Society (Westport, Conn.: Quorum Books, 2002); Livia Iacovino, "Archives as Arsenals of Accountability," in Currents of Archival Thinking (Santa Barbara, Calif.: Libraries Unlimited, 2010); Terry Eastwood, "Archives, Democratic Accountability, and Truth," in Better Off Forgetting?: Essays on Archives, Public Policy, and Collective Memory (Toronto: University of Toronto Press, 2010).

6 Albert Jacob Meijer, “Trust This Document! ICTs, Authentic Records and Accountability," Archival Science 3, no. 3 (2003): 275-90; Tom Nesmith, "Archivists and Public Affairs: Towards a New Archival Public Programming," in Better Off Forgetting? 
7 Douglas Cox, "Archives and Records in Armed Conflict: International Law and the Current Debate over Iraqi Records and Archives," Catholic University Law Review 59, no. 4 (2010): 1001-56; Michelle Caswell, “'Thank You Very Much, Now Give Them Back': Cultural Property and the Fight over the Iraqi Baath Party Records,” The American Archivist 74, no. 1 (2011): 211-40; Bruce Montgomery, “Saddam Hussein's Records of Atrocity: Seizure, Removal, and Restitution," The American Archivist 75, no. 2 (2012): 326-70; Saad Eskander, Recovering Iraqi Records, Transcript, GSLISCast (October 22, 2009), http://gslis.simmons.edu/podcasts/podcast_extras/2011/transcripts/RecoveringIraqiRecords _transcript.htm.

8 For an informative overview of this topic, see Richard Cox, "Archives, War, and Memory: Building a Framework," Library and Archival Security 25, no. 1 (2012): 21-57. For additional discussion of the complications related to decisions about preservation and intentional cultural destruction, see Michèle Valerie Cloonan, "The Paradox of Preservation," Library Trends 56, no. 1 (2007): 133-47.

9 Sir Hilary Jenkinson, writing in 1922 about the large volume of war records and the problem of many duplicate documents shared between wartime organizations, suggested that this issue might provoke new destruction and selection principles for war archives. The concept of "weeding" introduced here by Jenkinson as a necessity due to the burgeoning tide of records contrasts with his thoughts earlier in the same manual about archivists destroying records. Sir Hilary Jenkinson, A Manual of Archive Administration Including the Problems of War Archives and Archives Making (Oxford: Clarendon Press, 1922), 167-72.

${ }^{10}$ This claim is broadly informed by macro-appraisal, an appraisal theory and framework of practice developed in the early 1990s by Library and Archives Canada-then called the National Archives of Canada-to document Canadian society by appraising government records for how they provided evidence of Canada-its society, people, culture, and history-not just the Canadian government. For an overview of macro-appraisal, see Catherine Bailey, "From the Top Down: The Practice of Macro-appraisal," Archivaria 43 (Spring 1997): 89-128; Terry Cook, "Macro-appraisal and Functional Analysis: Documenting Governance Rather than Government," Journal of the Society of Archivists 25, no. 1 (April 2004): 5-18; Terry Cook, "Macroappraisal in Theory and Practice: Origins, Characteristics, and Implementation in Canada, 1950-2000," Archival Science 5, nos. 2-4 (2005): 101-61.

${ }^{11}$ Department of Defense, “Counterinsurgency,” DoD Dictionary of Military and Associated Terms, Joint Publication 1-02 (Washington, D.C.: Department of Defense, 2010).

12 “'Kinetic' capabilities focus on destroying enemy forces through the application of physical effects. . . . 'Non-kinetic' capabilities . . . [are] all other capabilities relevant to irregular warfare.” Kinetic activities usually refer to violently "neutralizing enemy forces" while nonkinetic activities refer to nonviolent actions undertaken to indirectly defeat insurgent forces, such as supporting the "security and well-being of the host nation population, the stability of the host nation government, and the coordination of military and civilian activities." W. J. Hurley et al., Non-Kinetic Capabilities for Irregular Warfare: Four Case Studies, IDA Paper (Alexandria, Va.: Institute for Defense Analyses, March 2009), ES-1, 1.

${ }^{13}$ Numerous works discuss America's performance in the Iraq War. Some of the most prominent ones include: Rajiv Chandrasekaran, Imperial Life in the Emerald City: Inside Iraq's Green Zone (New York: Alfred A. Knopf, 2006); George Packer, The Assassins' Gate: America in Iraq (New York: Farrar, Straus and Giroux, 2006); Thomas Ricks, Fiasco: The American Military Adventure in Iraq (New York: Penguin Press, 2006); Thomas Ricks, The Gamble: General David Petraeus and the American Military Adventure in Iraq, 2006-2008 (New York: Penguin Press, 2009); Michael R. Gordon and Bernard E. Trainor, The Endgame: The Inside Story of the Struggle for Iraq, from George W. Bush to Barack Obama (New York: Pantheon Books, 2012).

${ }^{14}$ Some of the key works in 2005 and 2006 that advocated a COIN approach in Iraq included Eliot Cohen et al., "Principles, Imperatives, and Paradoxes of Counterinsurgency," Military Review (April 2006): 49-53; Andrew F. Krepinevich Jr., "How to Win in Iraq," Foreign Affairs 84, no. 5 (2005): 87-104; John Nagl, Learning to Eat Soup with a Knife: Counterinsurgency Lessons from Malaya and Vietnam (Chicago: University of Chicago Press, 2005); Lt. Col. David Kilcullen, “'Twenty-Eight Articles': Fundamentals of Company-level Counterinsurgency,” Military Review (June 2006): 103-8; Kalev I. Sepp, "Best Practices in Counterinsurgency," Military Review (June 2005): 8-12; Lt. Col. Douglas A. Ollivant and Lt. Eric D. Chewning, "Producing Victory: Rethinking Conventional Forces in COIN Operations,” Military Review (August 2006): 50-59. 
${ }^{15}$ For more on the formulation and implementation of the surge strategy, see Ricks, The Gamble, 111-22, 159-69.

${ }^{16}$ Kilcullen, “Twenty-Eight Articles': Fundamentals of Company-level Counterinsurgency,” 105.

${ }^{17}$ Cohen et al. claim "the best weapons for counterinsurgency do not fire bullets. Counterinsurgents achieve the most meaningful success by gaining popular support and legitimacy for the host government, not by killing insurgents." "Principles, Imperatives, and Paradoxes of Counterinsurgency," 51.

${ }^{18}$ Kilcullen, “'Twenty-Eight Articles’: Fundamentals of Company-level Counterinsurgency,” 105.

${ }^{19}$ Headquarters, Department of the Army, Military History Operations, Field Manual 1-20 (Washington, D.C.: Headquarters, Department of the Army, February 3, 2003), chapter 5, page 4; Headquarters, Department of the Army, Journals and Journal Files, Army Regulation 220-15 (Washington, D.C.: Headquarters, Department of the Army, December 1, 1983).

${ }^{20}$ Department of the Army, Guide to Recordkeeping in the Army, Pamphlet 25-403 (Washington, D.C.: Department of the Army, August 11, 2008); Chairman of the Joint Chiefs of Staff, Joint Staff and Combatant Command Records Management Manual: Volume 1-Procedures, CJCSM 5760.01A, vol. 1 (Washington, D.C.: Chairman of the Joint Chiefs of Staff, February 7, 2008).

${ }^{21}$ For a detailed illustration of the critical political and strategic role that junior officers played in the Iraq War, even before the 2007 surge, see George Packer's account of U.S. Army captain John Prior in The Assassins' Gate, 220-234.

${ }^{22}$ Cohen et al.,"Principles, Imperatives, and Paradoxes of Counterinsurgency,” 51.

${ }^{23}$ Kilcullen, “'Twenty-Eight Articles’: Fundamentals of Company-level Counterinsurgency,” 104.

${ }^{24}$ Hans Booms, "Uberlieferungsbilding: Keeping Archives as a Social and Political Activity," Archivaria 33 (Winter 1991-1992): 27.

${ }^{25}$ Gen. Charles C. Krulak, "The Strategic Corporal: Leadership in the Three Block War," Marines Magazine, January 1999, http://www.au.af.mil/au/awc/awcgate/usmc/strategic_corporal.htm.

${ }^{26}$ These actions are not always positive. See, for example, the consequences of a U.S. Army sergeant massacring sixteen Afghan civilians in March 2012. James R. Holmes, “The Strategic Corporal's Evil Twin,” The Diplomat, March 18, 2012, http://thediplomat.com/2012/03/18/the-strategic-corporal \%E2\%80\%99s-evil-twin/.

${ }^{27}$ Frank Upward, "Structuring the Records Continuum Part One: Post-custodial Principles and Properties," Archives and Manuscripts 24, no. 2 (1996): 268-85; Frank Upward, "Structuring the Records Continuum Part Two: Structuration Theory and Recordkeeping," Archives and Manuscripts 25, no. 1 (1997): 10-35.

${ }^{28}$ Frank Upward, Sue McKemmish, and Barbara Reed, "Archivists and Changing Social and Information Spaces: A Continuum Approach to Recordkeeping and Archiving in Online Cultures," Archivaria 72 (Fall 2011): 197-237.

${ }^{29}$ Headquarters, Department of the Army, Military History Operations, 3-5; Center for Army Lessons Learned, U.S. Army Center of Military History, and U.S. Army Records Management and Declassification Agency, Commander's Guide to Operational Records and Data Collection (U.S. Army Center of Military History; U.S. Army Records Management and Declassification Agency; Center for Army Lessons Learned, March 2009), 6.

${ }^{30}$ For example, the U.S. Army Records Management and Declassification Agency has a permanent retention period for Designated Combat Environment/Wartime Records: "records [that] concern but are not limited to the operational records of Army forces deployed in combat or designated wartime environment, contingency operations for which documentation of said records will serve as institutional and historical purposes." Designated Combat Environment/Wartime Records, Contingency Operations (CONOPS), Army Consolidated Records Schedule (ACRS) (Washington, D.C.: U.S. Army Records Management and Declassification Agency), https://www.arims.army.mil/ARIMS /RRSA/ViewDetail.aspx?InstructID=17089. The Joint Chiefs of Staff also designates a wide range of records documenting contingency operations (which include the Iraq and Afghanistan wars) for preservation. Chairman of the Joint Chiefs of Staff, Joint Staff and Combatant Command Records Management Manual: Volume 1-Procedures, B-4. More generally, at the start of the Iraq war, the deputy secretary of defense noted that "it is of the utmost importance . . that we preserve the historical record of the current experience pertaining to Iraq. . . . To this end, all elements of 
the Department of Defense should identify, collect, organize, and preserve records, including paper, electronic media, imagery and recorded information pertinent to activities in connection with current and projected operations." Paul Wolfowitz, "Historical Records Pertaining to Iraq" (Department of Defense, March 28, 2003), ProPublica, http://www.propublica.org/documents |item/403778-dr-chu-dod-letter-15-aug-03\#document/p12/a80778 and http://s3.documentcloud.org /documents/403778/dr-chu-dod-letter-15-aug-03.pdf. Also see Chairman of the Joint Chiefs of Staff, Preservation of Historical Records of Operations Enduring Freedom and Noble Eagle and Pertaining to Iraq CJCSN 5760 (Washington, D.C.: Chairman of the Joint Chiefs of Staff, September 7, 2006).

${ }^{31}$ Rosa Brooks, “Welfare State,” Foreign Policy, July 19, 2012, http://www.foreignpolicy.com/articles/2012 /07/19/welfare_state.

${ }^{32}$ Mark Mazzetti, The Way of the Knife: The CIA, a Secret Army, and a War at the Ends of the Earth (New York: Penguin Press, 2013)

${ }^{33}$ Rosa Brooks, "Fog of War," Foreign Policy, August 8, 2012, http://www.foreignpolicy.com/articles |2012/08/08/fog_of_war; Brooks, "Welfare State."

${ }^{34}$ For insights on the nature of state-sponsored cyber-warfare, see the account of the American and Israeli cyber-attack on Iranian nuclear centrifuges in David E. Sanger, Confront and Conceal: Obama's Secret Wars and Surprising Use of American Power (New York: Crown Publishers, 2012), 188-225. Additional discussions at the State Department regarding the standing rules of engagement for cyberwarfare remain ongoing. See Ellen Nakashima, "In Cyberwarfare, Rules of Engagement Still Hard to Define,” Washington Post, March 10, 2013, http://articles.washingtonpost.com/2013-03-10/world |37605577_1_officials-debate-cyber-command-attack.

${ }^{35}$ Military blogs, or "milblogs," are a subset of "warblogs," blogs written by soldiers or veterans and almost exclusively about war. Early versions of warblogs appeared around the start of Operation Enduring Freedom in Afghanistan in 2001, and rising numbers of warbloggers coincided with the U.S.-led invasion of Iraq in 2003. The posts of some prolific early milbloggers have been turned into books, including Colby Buzzell, My War: Killing Time in Iraq (New York: G.P. Putnam's Sons, 2005); Matt Gallagher, Kaboom: Embracing the Suck in a Savage Little War (Cambridge, Mass.: Da Capo Press, 2010); Matthew Currier Burden, The Blog of War: Front-line Dispatches from Soldiers in Iraq and Afghanistan (New York: Simon and Schuster Paperbacks, 2006). For an overview of milblogs as considered by archivists, see Kaitlyn Medley, "Keep It Down Over There! Milblogs: Evidence That Historic Things Happen," Journal of Archival Organization 9, nos. 3-4 (2011): 141-73.

${ }^{36}$ Zack Baddorf, "U.S. Central Command Takes Responsibility for One of World’s Largest War Records Collection," March 15, 2011, United States Central Command, http://www.centcom.mil/news/u-s -central-command-takes-responsibility-for-one-of-world-s-largest-war-records-collection.html.

${ }^{37}$ John M. McHugh, "Letter to Representative Jeff Miller and Representative Michael H. Michaud," July 1, 2013, ProPublica, http://www.propublica.org/documents/item/726201-rep-miller-pdf-adobe -acrobat-pro and http://s3.documentcloud.org/documents/726201/rep-miller-pdf-adobe-acrobat -pro.pdf.

${ }^{38}$ Joseph Vine, "Archiving Detainee Records Requires Massive Guard Effort," National Guard 64, no. 12 (December 2010): 44-45.

${ }^{39}$ Chris Young, “Military Intelligence Redefined: Big Data in the Battlefield," Forbes, March 12, 2012, http://www.forbes.com/sites/techonomy/2012/03/12/military-intelligence-redefined-big-data-in-the -battlefield/.

${ }^{40}$ Joel W. Westphal, "The War on Records: The Collection, Preservation, and Processing of the Operation Iraqi Freedom Collection at United States Central Command" (presented at the Society of American Archivists and Council of State Archivists Joint Annual Meeting, New Orleans, August 17, 2013). A summary of this presentation written by Mimi Dionne is at "Thinking Beyond the Box: How Military Archivists Are Meeting 21st Century Challenges \#saa13," CMSWire.com, August 22, 2013, http://www.cmswire.com/cms/information-management/thinking-beyond-the-box-how -military-archivists-are-meeting-21st-century-challenges-saa13-022214.php.

${ }^{41}$ William Underwood and Sandra Laib, Automatic Recognition of Documentary Forms (Atlanta: Georgia Tech Research Institute, May 2008), http://perpos.gtri.gatech.edu/publications/TR\%2008-02.pdf; William Underwood, Recognizing Speech Acts in Presidential E-records (Atlanta: Georgia Tech Research Institute, October 2008), http://perpos.gtri.gatech.edu/publications/TR\%2008-03.pdf; William 
Underwood, "Grammar-Based Recognition of Documentary Forms and Extraction of Metadata," International Journal of Digital Curation 1, no. 5 (2010): 148-59.

${ }^{42}$ MIRC is a proprietary Microsoft Chat tool communicating over Internet Relay Chat. The use of simple text chat was used widely as an effective tactical communications strategy within the distributed, low bandwidth environment common during the early days of the war. Internet Relay Chat (IRC) was used for a variety of purposes that required fast, simple communication between various units and entities.

${ }^{43}$ Nancy J. Heacox et al., "Real-time Online Communications: 'Chat' Use in Navy Operations," in Proceedings of the 2004 Command and Control Research and Technology Symposium (San Diego, 2004), http://www.dtic.mil/cgi-bin/GetTRDoc?AD=ADA465828.

${ }^{44}$ Soldiers engaged in milblogging while deployed in Iraq and Afghanistan were subject to censorship by the military at various times. Early mention of blogs as an operational security concern came in August 2005 by General Peter Schoomaker, army chief of staff. In April 2005, Lieutenant General John Vines, commanding officer at the headquarters of the Multi-National Corps in Baghdad, Iraq, issued the "Multi-National Corps Policy (MNC-9) on Unit and Soldier Owned and Maintained Websites," requiring milbloggers to register with the command structure to ensure compliance with operational security regulations. Army Regulation (AR) 530-1 in April 2007 went further as a compliance measure on milblogging. Finally, in February 2010, a comprehensive measure, Directive-Type Memo (DTM) 09-026 was released as the first Department of Defense official policy on social media, allowing milblogging. The Department of Defense social media hub has links to official military blogs and blog policies at http://www.defense.gov/socialmedia/. For a discussion of milblogging legal issues and censorship, see K. C. D. Bleyker, "The First Amendment Versus Operational Security: Where Should the Milblogging Balance Lie?," Fordham Intellectual Property, Media and Entertainment Law Journal 17, no. 2 (2006): 401-42.

${ }^{45}$ The intent of many deployed and veteran milbloggers was not just to create a diary of their experiences, but to set the record straight and to tell the stories that they felt were being missed by mainstream media. Meanwhile, the accessibility of milblogs in real time had a significant effect on the practice of journalism and war reporting. See Daniel Bennett, “The Impact of Blogging on the BBC's Coverage of War and Terrorism” (diss., King's College London, 2011).

${ }^{46}$ The success of these informal forums led army knowledge management teams to create and administer additional forums under the umbrella of Battle Command Knowledge Systems (BCKS).

${ }^{47}$ For further information about the establishment of Company Command, Platoon Leader, and other professional forums explicitly created by soldiers as informal workspaces, see Nancy M. Dixon et al., CompanyCommand: Unleashing the Power of the Army Profession (West Point, N.Y.: Center for the Advancement of Leader Development and Organizational Learning, 2005).

${ }^{48}$ Captain Travis Patriquin, "How to Win the War in Al Anbar," http://abcnews.go.com/images/ US/how_to_win_in_anbar_v4.pdf (2006); Chad M. Pillai, “A Tribute to Captain Travis Patriquin: America's 'Lawrence of Arabia' in Ramadi,” SWJ Blog, December 8, 2010, http://smallwarsjournal. com/blog/a-tribute-to-captain-travis-patriquin. U.S. Army captain Travis Patriquin was killed by an improvised explosive device on December 6, 2006. For a biography of Captain Patriquin, see William Doyle, A Soldier's Dream: Captain Travis Patriquin and the Awakening of Iraq (New York: New American Library, 2011).

${ }^{49}$ Ricks, The Gamble, 27-28. Later versions of this document have been published in other languages and venues, and since the initial email, it has been formalized as Annex A of Field Manual 3-24, the U.S. Army and Marine Corps' counterinsurgency doctrine.

${ }^{50}$ This figure is just for the U.S. Army and is derived from the U.S. Army Unmanned Aircraft Systems Center of Excellence, Eyes of the Army: U.S. Army Unmanned Aircraft Systems Roadmap 20102035 (Fort Rucker, Ala.: U.S. Army Unmanned Aircraft Systems Center of Excellence, 2010), http:// www.rucker.army.mil/usaace/uas/US\%20Army\%20UAS\%20RoadMap\%202010\%202035.pdf; Larry Greenemeier, “The Drone Wars: 9/11-Inspired Combat Leans Heavily on Robot Aircraft," Scientific American, September 2, 2011, http://www.scientificamerican.com/article.cfm?id=post-911-military -tech-drones. The military defines reconnaissance as an operation that uses assets to observe an area to collect information; it further defines surveillance as the systematic observation of a particular area. Once the information from those operations has been analyzed and evaluated, it is referred to as intelligence. See Congressional Budget Office, Policy Options for Unmanned Aircraft 
Systems (Washington, D.C.: Congressional Budget Office, June 2011), http://www.cbo.gov/publication 141448.

${ }^{51}$ Ellen Nakashima and Craig Whitlock, "With Air Force's Gorgon Drone 'We Can See Everything', Washington Post, January 2, 2011, sec. Nation, http://www.washingtonpost.com/wp-dyn/content /article/2011/01/01/AR2011010102690.html.

${ }^{52}$ Eli Lake, "Drone Footage Overwhelms Analysts," Washington Times, http://www.washingtontimes .com/news/2010/nov/9/drone-footage-overwhelming-analysts/; Christopher Drew, "Military Is Awash in Data From Drones," New York Times, January 11, 2010, sec. Business, http://www.nytimes.com /2010/01/11/business/11drone.html; Maj. Gen. Michael T. Flynn, Cpt. Matt Pottinger, and Paul D Batchelor, Fixing Intel: A Blueprint for Making Intelligence Relevant in Afghanistan (Washington, D.C.: Center for a New American Security, 2010), www.cnas.org/files/documents/publications |AfghanIntel_Flynn_Jan2010_code507_voices.pdf; Ben Connable, Military Intelligence Fusion for Complex Operations: A New Paradigm, occasional paper (Santa Monica, Calif.: RAND Corporation, 2012).

${ }^{53}$ Spencer Ackerman, “Air Force Chief: It'll Be 'Years' before We Catch Up on Drone Data,” Wired, Danger Room, April 5, 2012, http://www.wired.com/dangerroom/2012/04/air-force-drone-data/.

54 “DARPA Kicks Off Mind's Eye Program,” January 4, 2011, DARPA, http://www.darpa.mil/NewsEvents/ Releases/2011/2011/01/04_DARPA_Kicks_Off_Mind\%E2\%80\%99s_Eye_Program.aspx.

55 “Mind's Eye to Identify and Predict Human Activities from Video" (2013), Carnegie Mellon University Robotics Institute, National Robotics Engineering Center, http://www.rec.ri.cmu.edu /about/news/11_01_minds.php; Alessandro Oltramari and Christian Lebiere, "Using Ontologies in a Cognitive-Grounded System: Automatic Action Recognition in Video Surveillance," in Proceedings of the Seventh International Conference on Semantic Technologies for Intelligence, Defense, and Security, ed. Paulo Cesar G. da Costa and Kathryn B. Laskey (Fairfax, VA: George Mason University, October 23-26, 2012), 20-27, http://dl.packetstormsecurity.net/papers/general/STIDS2012_T02 _OltramariLebiere_CognitiveGroundedSystem.pdf.

${ }^{56}$ Peter Sleeth and Hal Bernton, "Lost to History: Missing War Records Complicate Benefit Claims by Iraq, Afghanistan Veterans,” ProPublica, November 9, 2012, http://www.propublica.org/article/lost -to-history-missing-war-records-complicate-benefit-claims-by-veterans. Additional articles in the ProPublica series, "Lost to History: When War Records Go Missing," are at http://www.propublica .org/series/lost-to-history.

${ }^{57}$ Frank Shirer, "Army Records Preservation and Collecting the Records of Overseas Contingency Operations” (U.S. Army Center of Military History, 2009), 16-17, http://www.propublica.org/documents/item/403788-cah-2009-presentation and http://s3.documentcloud.org/documents/403788/ cah-2009-presentation.pdf.

${ }^{58}$ Michael Carlson and John Powell, “Trip Report, USF-I Records Management Assessment, April 3-10, 2010" (National Archives and Records Administration, April 22, 2010), 3, http://www.propublica.org /documents/item/403775-nara-trip-reportandhttp://s3.documentcloud.org/documents/403775/nara -trip-report.pdf.

59 Peter Sleeth, “A Son Lost in Iraq, but Where Is the Casualty Report?,” ProPublica, November 12, 2012, http://www.propublica.org/article/a-son-lost-in-iraq-but-where-is-the-casualty-report; Peter Sleeth, "Veterans' Advocate to Congress: Reconstruct Missing War Records," ProPublica, December 5, 2012, http://www.propublica.org/article/veterans-advocate-to-congress-reconstruct-missing-war-records; Wading through Warehouses of Paper: The Challenges of Transitioning Veterans Records to Paperless Technology (Washington, D.C., 2012), House Committee on Veterans Affairs, http://veterans.house.gov/hearing /wading-through-warehouses-of-paper-the-challenges-of-transitioning-veterans-records-to.

${ }^{60}$ Carlson and Powell, "Trip Report," 4.

${ }^{61}$ Sleeth and Bernton, "Lost to History: Missing War Records Complicate Benefit Claims by Iraq, Afghanistan Veterans”; Carlson and Powell, “Trip Report," 4.

${ }^{62}$ Richard W. Stewart, "Army Operational Records, Data Collection, and Readiness" (AAMH-ZC, February 20, 2009), http://www.propublica.org/documents/item/510007-stewart-paper and http:/ s3.documentcloud.org/documents/510007/stewart-paper.pdf.

${ }^{63}$ Carlson and Powell, “Trip Report,” 3.

${ }^{64}$ Joint Staff Secretariat Information Management Division, “Assessment of United States Forces-Iraq Records and Records Management Activities” (June 2010), 5, http://www.propublica.org/documents 
/item/403789-joint-records-collection-effort-cy07-1, http://s3.documentcloud.org/documents/403789 /joint-records-collection-effort-cy07-1.pdf, and http://www.dod.mil/pubs/foi/administration_and _Management/admin_matters/12-F-0679_Assessment_of_United_States_Forces-Iraq_Records _and_Record_Management_Activities.pdf.

${ }^{65}$ Stewart, "Army Operational Records, Data Collection, and Readiness," 7.

${ }^{66}$ Sleeth and Bernton, "Lost to History: Missing War Records Complicate Benefit Claims by Iraq, Afghanistan Veterans.”

${ }^{67}$ Stewart, "Army Operational Records, Data Collection, and Readiness," 7.

${ }^{68}$ Center for Army Lessons Learned, U.S. Army Center of Military History, and U.S. Army Records Management and Declassification Agency, Commander's Guide to Operational Records and Data Collection, 12.

${ }^{69}$ Center for Army Lessons Learned, U.S. Army Center of Military History, and U.S. Army Records Management and Declassification Agency, Commander's Guide to Operational Records and Data Collection, 6-7.

${ }^{70}$ Ben Connable, Embracing the Fog of War: Assessment and Metrics in Counterinsurgency (Santa Monica, Calif:: RAND Corporation, 2012), 223.

${ }^{71}$ Headquarters, Department of the Army, Military History Operations, chapter 1, page 1; Center for Army Lessons Learned, U.S. Army Center of Military History, and U.S. Army Records Management and Declassification Agency, Commander's Guide to Operational Records and Data Collection, i, 1-3; U.S. Army Center of Military History, Organizational History (Washington, D.C.: U.S. Army Center of Military History, 1999), 1-5.

${ }^{72}$ Sleeth and Bernton, "Lost to History: Missing War Records Complicate Benefit Claims by Iraq, Afghanistan Veterans."

${ }^{73}$ Stewart, "Army Operational Records, Data Collection, and Readiness," 6.

${ }^{74}$ Westphal, "The War on Records: The Collection, Preservation, and Processing of the Operation Iraqi Freedom Collection at United States Central Command"; Dionne, "Thinking Beyond the Box."

${ }^{75}$ James Ginther, "Telling the Whole Story: Capturing the Military Experience when the Official Records Fail" (presented at the Society of American Archivists and Council of State Archivists Joint Annual Meeting, New Orleans, August 17, 2013).

${ }^{76}$ Stewart, "Army Operational Records, Data Collection, and Readiness," 5-6; Carlson and Powell, "Trip Report," 3-4. The work of the MHDs echoes the efforts of the Canadian War Records Office which sent field historians to the Western Front to collect records from units in the Canadian Expeditionary Force during the First World War. Tim Cook, Clio's Warriors: Canadian Historians and the Writing of the World Wars (Vancouver: UBC Press, 2006), 21-24.

${ }^{77}$ Department of the Army Historical Advisory Committee, "Department of the Army Historical Advisory Committee, Proceedings, 26 October 2006," 10, http://www.propublica.org/documents/ item/510024-2006-dahac-minutes and http://s3.documentcloud.org/documents/510024/2006-dahac -minutes.pdf.

${ }^{78}$ Headquarters, Department of the Army, Military History Operations, chapter 4, page 1.

${ }^{79}$ Shirer, "Army Records Preservation and Collecting the Records of Overseas Contingency Operations,” 13.

${ }^{80}$ For a review of document and interview collection responsibilities, see Headquarters, Department of the Army, Military History Operations; Headquarters, Department of the Army, Military History: Responsibilities, Policies, and Procedures, Army Regulation 870-5 (Washington, D.C.: Headquarters, Department of the Army, September 21, 2007).

${ }^{81}$ David Hanselman, "The Tip of the History Spear: Capturing Combat History of the Army in Current Operations," The Federalists: Newsletter of the Society for History in the Federal Government, Second Series, no. 24 (Winter 2009-2010): 9.

${ }^{82}$ Additional media coverage includes Gerry Brown and Andrew Shaver, "America's Disappearing War Data," The National Interest, August 8, 2013, http://nationalinterest.org/commentary/ americas-disappearing-war-data-8851;Peter Sleeth, "U.S. Army Conducts Search for Missing Wartime Documents," Salon, July 16, 2013, http://www.salon.com/2013/07/16/u_s_army_conducts_search _for_missing_wartime_records_partner|; Peter Sleeth, “Army Admits Thousands of War Records 
Are Missing," Army Times, July 24, 2013, http://www.armytimes.com/apps/pbcs.dll/article?AID $=2013307240001$.

${ }^{83}$ Peter Sleeth, "Congressmen to Hagel: Where Are the Missing War Records?,” ProPublica, May 20, 2013, http://www.propublica.org/article/congressmen-to-hagel-where-are-the-missing-war-records; Rep. Jeff Miller and Rep. Michael H. Michaud, “Letter to Chuck Hagel,” May 17, 2013, https://www .documentcloud.org/documents/702178-dod-missingrecords-followup-2-17-2013-1.html and https:/ s3.amazonaws.com/s3.documentcloud.org/documents/702178/dod-missingrecords-followup -2-17-2013-1.pdf; McHugh, "Letter to Representative Jeff Miller and Representative Michael H. Michaud."

${ }^{84}$ McHugh, "Letter to Representative Jeff Miller and Representative Michael H. Michaud”; Peter Sleeth, “Army Says War Records Gap Is Real, Launches Recovery Effort,” ProPublica, July 12, 2013, http://www.propublica.org/article/army-says-war-records-gap-is-real-launches-recovery-effort.

${ }^{85}$ McHugh, "Letter to Representative Jeff Miller and Representative Michael H. Michaud.”

${ }^{86}$ Gen. Raymond T. Odierno and John M. McHugh, "Collection of U.S. Army Records from Operation Enduring Freedom, Operation Iraqi Freedom and Operation New Dawn,” July 1, 2013, http://www .propublica.org/documents/item/726200-recordkeeping-2013-memo and http://s3.documentcloud .org/documents/726200/recordkeeping-2013-memo.pdf; McHugh, “Letter to Representative Jeff Miller and Representative Michael H. Michaud."

${ }^{87}$ Odierno and McHugh, "Collection of U.S. Army Records From Operation Enduring Freedom, Operation Iraqi Freedom and Operation New Dawn."

${ }^{88}$ Department of the Army, Guide to Recordkeeping in the Army, 63.

${ }^{89}$ Center for Army Lessons Learned, U.S. Army Center of Military History, and U.S. Army Records Management and Declassification Agency, Commander's Guide to Operational Records and Data Collection, 1.

${ }^{90}$ For examples of one archives preserving personal materials and another documenting operational records from the Vietnam War, see Michael Stevens, "Voices from Vietnam: Building a Collection from a Controversial War," The American Archivist 64, no. 1 (Spring/Summer 2001): 115-20 and Donald Fisher Harrison, “Computers, Electronic Data, and the Vietnam War,” Archivaria 26 (1988): 18-32.

${ }^{91}$ Timothy L. Ericson, “Building Our Own 'Iron Curtain': The Emergence of Secrecy in American Government," The American Archivist 68, no. 1 (Spring/Summer 2005): 18-52.

${ }^{92}$ Cassie Findlay, "People, Records and Power: What Archives Can Learn from WikiLeaks," Archives and Manuscripts 41, no. 1 (2013): 7-22; Alex Byrne, "WikiLeaks and Web 2.0: Privacy, Security and Other Things That Keep Me Awake ..., ," Archives and Manuscripts 39, no. 1 (2011): 49-66.

${ }^{93}$ Sleeth, “Veterans' Advocate to Congress: Reconstruct Missing War Records”; Sleeth, “Army Says War Records Gap Is Real, Launches Recovery Effort"; Sleeth, "Congressmen to Hagel: Where Are the Missing War Records?"

${ }^{94}$ Advocacy for veterans' records has been an effective strategy in the past, leading to political support for the establishment of a "hall of records" that eventually became the National Archives and Records Administration. Victor Gondos, J. Franklin Jameson and the Birth of the National Archives, 1906-1926 (Philadelphia: University of Pennsylvania Press, 1981), 31-35.

${ }^{95}$ Jeannette Bastian, "Flowers for Homestead: A Case Study in Archives and Collective Memory," The American Archivist 72 (Spring/Summer 2009): 131. 
ABOUT THE AUTHORS
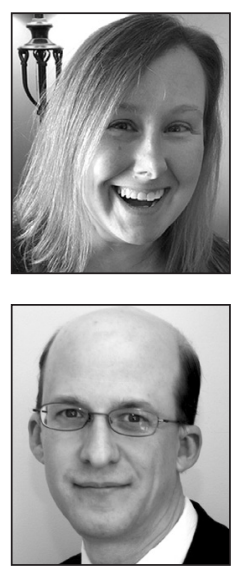

Heather Soyka is a doctoral candidate and teaching fellow in archival studies at the School of Information Sciences, University of Pittsburgh. Her research interests include recordkeeping behavior, documentation of war and conflict, community recordkeeping, and the relationships between organizational and personal records. She has previously held positions as the head of preservation and assistant university archivist at Texas Tech University. She received her master's degree from the Simmons College Graduate School of Library and Information Science.

Eliot Wilczek is the acting director of the Digital Collections and Archives at Tufts University. He previously served as the university records manager at Tufts and worked as an archivist at Brandeis University and Bowdoin College. He is also a doctoral candidate at the Graduate School of Library and Information Science, Simmons College. He has a master's degree in Library and Information Science and a master's in history, both from Simmons College. 